УДК 903.59

DOI $10.18411 /$ nbg-001

\title{
ОТКРЫТИЕ ЖЕЛЕЗА ДРЕВНИМИ
}

\author{
Соловьев Сергей Юрьевич, \\ Москва, РФ
}

\begin{abstract}
Аннотация: Предметом исследования является факт открытия железа в глубокой древности. Сам факт открытия этого доступного металла привел к более быстрому технологическому и культурному развитию человечества. Главная цель настоящей статьи - раскрыть связь между религиозным обрядом посыпания охрой мертвых, переходом на кремацию и открытием железа. Сам человек в тех обстоятельствах не мог и представить, что из красной земли, а впоследствии камня-руды, можно получить сырье для высококачественных и прочных изделий. Причинно-следственную связь человек не смог бы обнаружить. Метод исследования в определении связи между развитием религии и культуры и технологическим рывком, открытием человеком новых технологий и материалов. Новизна данного исследования заключается в установлении причинно-следственной связи между культурными традициями и развитием новых технологий. Без перехода людей на кремацию с использованием охры открытие железа состоялось бы много позже, весьма вероятно, как с алюминием, открытым в 19 веке и включенным в технологическое развитие лишь в 20 веке.
\end{abstract}

Ключевые слова: охра; железо; кремация; захоронение; кровь; мертвый; руда; древние люди; обряд; открытие.

\section{THE DISCOVERY OF IRON IN ANCIENT}

\author{
Solov'yev Sergey Yur'yevich, \\ Moscow, Russia
}

Summary: The subject of research is the discovery of iron in ancient times. The fact of the discovery of this more available metal has led to more rapid technological and cultural development of mankind. The main goal of this paper is to reveal the connection between the religious rite of sprinkling the dead with ochre, the transition to cremation and the opening of the iron. The person in the circumstances could not imagine that the red earth and later of stone ore, can obtain raw material for high quality and durable products. A causal link a person is not able to detect. Method study-definition of the relationship between the development of religion and culture to a technological breakthrough, the discovery of new technologies and materials. The novelty of this research is to establish causal relationships between cultural traditions and the development of new technologies. Without moving people on cremation with the use of iron ochre discovery took place much later, it is highly likely, as with 
aluminium, open-in the 19th century and included in technological development only in the 20th century.

Keywords: ochre; iron; cremation; burial; blood; dead; ore; ancient people; a ritual opening; discovery.

Можно утверждать, что открытием железа мы обязаны применению древними людьми охры.

Охра - краска (пигмент), получаемая из железной руды, а именно из бурого железняка. Бурый железняк (лимонит) $-35 \ldots 55 \%$ железа в виде смеси гидроксидов трехвалентного железа $\mathrm{Fe}_{2} \mathrm{O}_{3}-3 \mathrm{H}_{2} \mathrm{O}$ и $\mathrm{Fe}_{2} \mathrm{O}_{3}-\mathrm{H}_{2} \mathrm{O}$.

Охра - это природный пигмент, который делали из гидрата окиси железа с добавлением глины. Образуется при смешивании определенного вида железной руды (лимонита или гематита) с глиной и измельчении получившегося продукта в порошок.

В древности употреблялся различными народами для религиозных церемоний, в похоронных обрядах, в росписях, в настоящее время служит основой красок желтых оттенков.

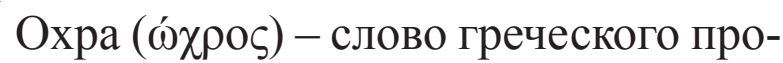
исхождения и в буквальном переводе означает бледно-желтый.

Самые ранние из сохранившихся в мире росписей - это картины пещеры Альтамира (Испания). Датируются эти росписи эпохой палеолита, древнекаменным веком в истории развития человечества. Наскальные рисунки в пещерах Шове (Франция) были сделаны нашими предками 32 тысячи лет назад.

На территории России самая известная находка - это Капова Пещера с росписями, датируемыми $15 \ldots 16$ тыс. до н. э. В Капову пещеру была организована экспедиция из института археологии Академии наук СССР под руковод- ством известного советского археолога, доктора исторических наук Отто Николаевича Бадера.

Жёлтая охра - смесь гидрата окиси железа с глиной, а красная - смесь безводной окиси железа с глиной.

Красная охра (железная охра) - землистый, порошковатый гематит красного цвета, наиболее широко используемый пигмент. Ее можно обнаружить еще в наскальных рисунках. В естественном состоянии ее можно найти в вулканических породах.

Красная охра готовится большей частью обжиганием жёлтой охры, то есть обезвоживается посредством нагревания встречающейся в изобилии в природе желтой охры. Использование красной охры (кровавика) в погребальном обряде было широко распространено в среде археологических культур каменного века - раннего металла лесной зоны Евразии. Значение охры не до конца ясно. Многие исследователи видят в ней заменитель крови, символ жизни после смерти.

Для того чтобы обеспечить исцеление или воскрешение, охрой покрывали тела умерших или тяжелобольных людей. Здесь понятна религиозная, магическая составляющая взгляда древних людей на красную охру, как кровь земли. Связь, возможно, такая - земля все сущее порождает, у всего живого есть кровь, и она красная, и кровь Земли может оживить человека после смерти или как-то облегчить его существование после смерти. 
Изображение животных на росписях именно красной или желтой краской означает, что изображали живых существ, изображений сделанных черной краской не найдено. Возможно, это было для мира мертвых. И следующая гипотеза - древние греки изображали на вазах черным пигментом только умерших, а живых - красным или белым цветом. Так что вероятно, традиции сохранялись. Праздничная брачная одежда в Риме была тоже красного цвета, как и в Индии брачный наряд у брачующихся.

Высказывались различные мнения о значении охры в могиле. Установлено, что она препятствует разложению трупов, распространению инфекции, т. е. обладает дезинфицирующими свойствами. Но более логично, что это все-таки религиозный аспект. Не поэтому ли древние посыпали умерших охрой? Дезинфицирующее свойство охры могло быть знакомо древним, но вряд ли погребенных ею посыпали из этих соображений. Об этом свидетельствуют данные археологии: охрой не просто посыпана могила. Охра располагалась в определенных местах: под глиняными сосудами, там, где лежат другие вещи, часто у ног погребенного, особенно у головы, пяток.

Охра имела, очевидно, магическое значение, как кровь земли. То есть как кровь прародителей, и может быть, Богини-Матери, чей культ связан с землей. Первые изображения женских статуэток примерно этого же возраста. В русском языке руда - кровь и значение руды металлов.

Охрой изображали сложные орнаменты на стенах могил и полу.

Уже в XIX - начале XX вв. архео- логами, изучавшими бронзовый век, были высказаны предположения (данные этнографии подтвердили это), что охра - имитация крови и огня [1, с. 151153]. Такой взгляд на охру господствует и сегодня [2, с. 188-197]. Сравните с

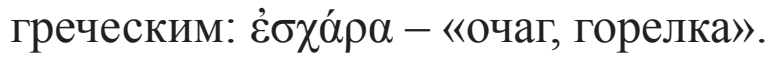

Кровь и огонь у многих народов древности и современности символизировали жизнь, воскрешение. Интересно, что эта идея укладывается в общее объяснение положения умершего, его ориентировку: умерший должен родиться вновь. То есть вера в Богиню-Мать была основана на веру в воскрешение после смерти.

В могилах, курганах, древних захоронениях, относящихся к дохристианской эпохе, находят яйца, как натуральные, так и выполненные из различных материалов (мрамор, глина и др.). При раскопках в этрусских гробницах обнаружены резные и натуральные страусовые, куриные яйца, иногда раскрашенные. Яйца во многих культурах - символ новой жизни. Как зарождение живого из неживого.

В Египте сохранились изображения расписных яиц, но неизвестно, с какой целью они делались (древние римляне красили яйца охрой и брали их с собой в храмы для очищения от грехов).

В эпоху верхнего палеолита развивается резьба на камне, кости, дереве, а также круглая пластика. Потом многие изделия окрашивались охрой.

Охра очень часто, почти повсеместно используется кроманьонцами, как в заупокойном ритуале, так и при иных религиозных обрядах, как принцип торжества жизни, как победа над смертью. Она символизирует кровь, жизнь, намерение оживить умерших через со- 
единение с веществом, имеющим цвет крови, а для древних людей являлся кровью земли.

Возможно и вероятно, что именно этот обычай положил начало устойчивой ассоциации «того света» с цветом крови во многих религиозных традициях. Много позднее красный пигмент использовался для росписей сакральных объектов, как Кносский Дворец. Его стены расписаны красным пигментом.

Вспомним русское «Красный угол». Вначале, очевидно просто красного цвета, потом в значении красивый.

Применение охры в погребальных обрядах прекращается в период поздней бронзы, что связано, по мнению исследователей, с изменившимся отношением к веществу, к охре, утратившей статус сакрального, статус крови Земли.

Итак, я утверждаю, что открытие железа связано с охрой и обычаем посыпания покойника при захоронении. Открытие железа произошло при переходе на кремацию - мертвого посыпали охрой и сжигали, при предании несгоревших останков обнаружили железо, восстановленное из охры (см. русское руда - кровь, руда - кровь земли).

Это произошло при переходе от ингумации к кремации, скорее всего исходя из логики - как умерший может быть одновременно на Земле и на небе, и не может возродится вновь пока тело-вместилище души не полностью разрушено. Почему не найдены соответствующие следы кремации со следа- ми железа? Ну, это примерно как требовать представить в Индии могилы индуистов.

Если имеет место факт кремации, то материальных следов практически не остается, тем более спустя тысячелетия.

Сначала, очевидно, считали, что железо получается из крови мертвого (кровь - руда, на старорусском), а не охры. С этим связаны представление о том, что кузнецы - колдуны, и каким-то магическим способом делают из крови железо.

Так что открытие железа связано одновременно с обычаем сжигания мертвых и посыпанием мертвых охрой. В России до 17 века сохранилась абсолютно древняя технология добычи так называемой «болотной руды», окислов железа, как раз красного цвета. Руда болотная очень высокого качества, без примесей серы, но очень дорогая и трудозатратная. Такая технология добычи железа неизвестна была в античном мире.

Поэтому можно говорить, что желе30 было открыто на просторах Евразии, (потому что абсолютно архаичный способ добычи железа сохранился только в России) где-то в начале 2 тыс. до н. э. Почему? Старейшие находки следов железа обнаружены в Трое, и датируются примерно этим же временем.

По другому бы люди не открыли железо. Как не открыли технологию добычи алюминия вплоть до 19 века.

\section{СПИСОК ЛИТЕРАТУРЫ}

1. Городцов В. А. Результаты археологических исследований в Изюмском уезде Харьковской губернии 1901 г. - Труды XII АС. - М., 1905, т. 1, - с. 151-153.

2. Балабина Б. И. К вопросу об использовании охры в катакомбных погребениях. 
Древности дона. Материалы работ Донской экспедиции. - М. : Наука, 1983. $253 \mathrm{c}$.

\section{REFERENCES}

1. Gorodtsov V. A. Rezul'taty arkheologicheskikh issledovaniy v Izyumskom uezde Khar'kovskoy gubernii 1901 g. - Trudy XII AS. - M., 1905, t. 1, - s. 151-153.

2. Balabina B. I. K voprosu ob ispol'zovanii okhry v katakombnykh pogrebeniyakh. Drevnosti dona. Materialy rabot Donskoy ekspeditsii. - M. : Nauka, 1983. - 253 c.

Материал поступил в редакцию 21.03.2017

(C) Соловьев С. Ю., 2017 